\title{
Estética do engajamento do itaú na \#instamission38
}

\section{Larissa Neves}

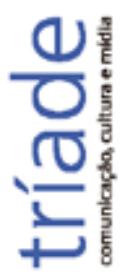

Universidade Federal da Bahia (UFBA), Programa de Pós- Graduação em Comunicação e Cultura Contemporâneas. Salvador, BA, Brasil. Contato com a autora: larissaneves1@ gmail.com

\section{Regina Gomes}

Universidade Federal da Bahia (UFBA), Programa de Pós- Graduação em Comunicação e Cultura Contemporâneas. Salvador, BA, Brasil. Contato com a autora: reginagomesbr@gmail.com 
Resumo: O presente artigo concebe a mídia social Instagram como cenário de convergência entre novas e velhas plataformas comunicacionais no intuito de examinar as estratégias de visualidade da produção publicitária imagética do \#Instamission38: "Fotografe o que transforma o mundo", promovida pelo banco Itaú. Utilizamos como metodologia de análise das imagens o sistema conceitual de Martine Joly (2007) e a noção de Branded Content (Covaleski, 2010; Santos, 2014), experiência comunicacional da marca ancorada na prática colaborativa de seus usuários. Concluímos que a marca Itaú se apropria da missão fotográfica e do imaginário simbólico cultural contemporâneo como estratégias de produção de uma estética do engajamento presente no regime de visualidade do consumo moderno.

Palavras-chave: Projeto fotográfico colaborativo. Marca. Engajamento.

Abstract: This article conceives the social media Instagram as a scenario of convergence between new and old communication platforms in order to examine the visual strategies of the image advertising production of \# Instamission38: "Photograph what transforms the world", promoted by the Itaú bank. We use as a methodology of image analysis the conceptual system of Martine Joly (2007) and the notion of Branded Content (Covaleski, 2010; Santos, 2014), communicational experience of the brand anchored in the collaborative practice of its users. We conclude that the Itaú brand appropriates the photographic mission and the contemporary cultural symbolic imagery as strategies to produce an aesthetic of the present engagement in the modernity visuality regime.

Keywords: Collaborative photo project. Brands. Engagement. 


\section{Introdução}

Fotografar valendo-se de smartphones especialmente via Instagram vem ancorando as representações imagéticas do nosso tempo e poderia ser apenas mais um hobby, um modo despretensioso de retratar o campo visual que nos cerca, no entanto, através do conceito de fotografia colaborativa proposto pelo Instamission entrelaçam-se as artimanhas da indústria do entretenimento e da publicidade.

Este movimento que alça o usuário à recente condição de prosumer ou prosumidor, produtor e concomitantemente consumidor de conteúdo, é fruto da convergência midiática e mostra-se ilustrativo para a compreensão de um novo modelo de publicidade atrelado ao conteúdo da marca, o Branded Content Digital. Assim, no presente artigo deseja-se compreender como o Itáu, instituição financeira privada, promove a adesão à prática fotográfica através do patrocínio à missão intitulada de \#Instamission38: "Fotografe o que transforma o mundo".

Ademais, o que depreender da relação entre novas plataformas, consumidores em rede e conteúdo de marca no que tange ao consumo e experiência? O que o Itaú propõe em termos imagéticos e simbólicos através da curadoria de fotografias que visam transformar o mundo? E por fim que dizem as fotografias selecionadas acerca das estratégias vigentes no regime de visualidade contemporâneo?

Baseados na metodologia de Martine Joly (2007) partiremos da análise das dez fotografias vencedoras da missão \#instamission38: "Fotografe o que transforma o mundo" reconstruindo-as nos níveis: plástico, icônico e simbólico-cultural (contribuição nossa) com o objetivo de contemplar diferentes camadas de sentido e suas distintas implicações. Ademais, convocaremos certos autores (SANTOS, 2014; COVALESKI, 2010; LIPOVETSKY, 2004, 2015) para tratar da questão da publicidade contemporânea, particularmente a noção de Branded Content decorrente do avanço das novas tecnologias da comunicação.

\section{O apelo do instamissions em tempos de publicidade hipermoderna}

A popularização de câmeras fotográficas acopladas a celulares conectados a internet, possibilitou a emergência do Instagram, mídia social que através do sistema touchscreen possibilita, a partir de um toque, instalar o aplicativo, realizar uma conta gratuita, fotografar ou filmar, editar e publicar imagens, encarnando o estado atual da produção e consumo imagético por tratar-se de "um conceito de fotografia em redes, instantâneo, de circulação mundial e que cabe no bolso" (SILVA JR, 2012, p.3).

É relevante salientar algumas reminiscências dos sites de compartilhamento, antecedentes que lhe acarretaram assimilações: particularmente a ideia de diário particular oriunda dos fotologs - sistema de photosharing pioneiro no país - agora ampliada por "momentos compartilhados", percepção reforçada pelo recurso de "feeds", em que as fotos de quem seguimos são atualizadas constantemente, proporcionando a sensação de um fluxo contínuo de produção de sentido. 
Outro exemplo sintomático faz menção ao uso de tags (utilizado então pelo Flick) e potencializado hoje pelas \#hashtags que não somente etiquetam as fotografias de acordo com palavras-chave, mas possibilitam a interação dinâmica do conteúdo com os outros integrantes da rede interessados no mesmo assunto, ou seja, funcionando como uma espécie de hiperlink, torna este conteúdo acessível para aqueles que usem a mesma \#hashtag, o que pode garantir que esta fotografia seja vista por multidões além de servir inclusive, para fins de monitoração e rastreamento de temas, visibilidade, popularidade, rejeição e reputação na rede, sem mencionar ainda seus usos com fins de engajamento publicitário, o que será explorado mais adiante.

O Instagram possui ainda, desde seu surgimento, características similares àquelas empregadas pela rede social Facebook como: perfis pessoais, rede de amigos, além do sistema de avaliação e também métrico para medir a popularidade das postagens (likes correspondem a corações), possibilidade de seguir e ser seguido, além do sistema de posicionamento geográfico (GPS) característico de mídias locativas como o Foursquare, o que o torna um dos mais populares sistemas de sensoriamento participativo em vigor.

Estes avanços denotam a convergência de funções expressa no celular que agora comunica ao falar, digitar e fotografar. Jenkins (2006) elucida que está proclamada convergência é antes de tudo um fenômeno cultural, pois refere-se a uma transformação mais profunda no modo de pensar e agir dos consumidores contemporâneos, que agora se apropriam dos dispositivos técnicos para produzir e partilhar sentidos.

Neste sentido, Lemos (2007) mostra que o cerne da questão recai sobre o atual protagonismo do usuário que representa hoje o centro do próprio processo comunicativo alterando a constituição, as dinâmicas e as rotinas dos meios de comunicação tradicionais, então fortemente centralizados. Decerto, enquanto os meios tradicionais analógicos estavam alicerçados perante a lógica do broadcasting na qual "um produz para muitos", o atual modelo representado pelo neocasting é capaz de delinear novas experiências de entretenimento em rede e, consequentemente, novos paradigmas aos mercados midiáticos.

A interatividade oferecida pelas tecnologias digitais, embora não sem limites e empecilhos, somada à convergência entre múltiplas plataformas e conteúdos demandam conexões complexas e inovadoras entre a própria indústria do entretenimento e a publicidade, instaurando deste modo uma paisagem favorável ao surgimento do Advertainment, uma proposta de fusão entre os referidos campos.

Esta comunicação por conteúdo, o Branded Content, conforme Santos (2014) se caracteriza por ter um teor pensado, elaborado e distribuído pela própria marca de modo independente, alinhado ao seu gerenciamento global em múltiplos canais. Atualmente, devido ao baixo custo de investimento e grande retorno em relacionamento e imagem, disseminase o uso do Digital Branded Content que promove o encontro do consumidor usuário das redes sociais digitais com os valores e posicionamento da marca, despertando uma relação de identificação e envolvimento a partir de conteúdos produzidos por esta.

Autores como Covaleski (2010) chegam a entrelaçar a prática do Branded Content 
à experiência digital ao afirmar que se trata de "uma publicidade mesclada ao conteúdo e transformada em entretenimento e que também se torna apta a interatividade e suscetível a ser compartilhada" (COVALESKI, 2010, p. 24). Em outros termos, o autor acredita que o conteúdo de marca só se efetiva plenamente ao ser realizado através da experiência online com vistas ao compartilhamento.

Ao conceber a fotografia enquanto propriedade comum, o Instagram adquire crescente importância, pois vai ao encontro do comportamento social urbano representado por 700 milhões de usuários ativos ${ }^{1}$ em todo o mundo, além de que o uso de hashtags implica um tipo de empenho no qual o indivíduo contribui ativamente para a construção de significados e sentidos atrelados à imagem fotográfica. Logo, esta mídia social mostra-se uma poderosa plataforma de construção de marca devido a capacidade de aliar narrativas centradas em imagens, pessoas e o seus respectivos lifestyle a produtos, gerando assim mídia espontânea em cada 1 bilhão de curtidas que são distribuídas diariamente, além de mais de mil comentários por segundo.

Se a história da visualidade aponta para uma visão centrada na perspectiva do observador, Gumbrecht (2006), por sua vez, defendeu que a estética do século XXI nos fala sobre um modo específico de apropriação do mundo, especialmente focado do cotidiano que impõe consigo cada vez mais efeitos de sentido e presença. Deste modo, não basta estar nos lugares e viver as circunstâncias, é necessário sentir e documentar esta experiência, convertendo-a em cores, volumes, captando impressões e criando outras tantas em fotografias, reforçando, como mencionamos, um ideal de vida hedonista fundado numa estética participativa apropriada pela comunicação marcária.

Neste cenário, ressaltamos o Instamission, projeto brasileiro de fotografia realizado colaborativamente via mídia social Instagram, cujo conceito consiste em lançar semanalmente um desafio dentro de um tema específico e deste modo encorajar os usuários do Instagram que são seguidores do Perfil do Instamission, a realizar e compartilhar fotos do seu dia a dia com a hahstag referente ao tema. A partir da terceira Instamission, algumas missões passaram a dar premiação às melhores fotos, e sua repercussão imediata motivou a criação de uma empresa, a agência Contente, responsável por elaborar temáticas e negociar patrocínios para as missões. Atualmente $^{2}$, o projeto colaborativo já conta com mais de 346 missões, que somam mais de 200 mil fotos, obtendo mais de 55,7 mil pessoas como seguidoras do perfil@instamission no Instagram.

O projeto colaborativo revela-se como um modo de atualizar a experiência dos concursos de fotografia, sendo também um modelo de negócio, pois substitui modelos convencionais nos quais campanhas publicitárias eram imaginadas e geridas "sob medida", pondo em seu

1 Informação obtida em: http://tecnologia.ig.com.br/2017-04-28/instagram-emnumeros.html.Acesso:22/09/2017.

2 Dados sobre o total de fotografias foram colhidos da entrevista à Revista Claúdia (versão digital) disponível em: https://casaclaudia.abril.com.br/ambientes/missao-fotografe-seu-quarto-e-coloque-no-instagram/, enquanto que o número de missões e seguidores foi coletado do perfil do Instamissions no Instagram: https://www. instagram.com/instamission. Acesso em 22/09/2017. 
lugar iniciativas que privilegiam o que o Festival de Publicidade de Cannes, o Cannes Lion, denomina como sendo o User-Generated Content, ou conteúdo gerado por usuário, enquanto estratégia que prevê a colaboração do usuário em sua instância criativa, desde que sob diretrizes bem definidas e alinhadas com os interesses da marca.

Esta nova geografia em que pequenos grupos alcançam relevância e preponderância obedece à lógica proposta pela teoria da cauda longa ${ }^{3}$, em que a redução dos custos de distribuição acaba por refinar por consequência o conceito de público-alvo ou target. As marcas conquistam a visibilidade desejada e um elevado grau de envolvimento destes prosumidores tanto na produção, quanto na disseminação desse conteúdo em suas redes.

É preciso antes compreender as próprias modificações sofridas pelo termo engajamento que com o tempo passou do francês medieval "engage", simbolizando o ato de "dar garantia", para adquirir no século XX o sentido de comprometimento com uma causa. Assim, engajar-se é, antes de tudo, ter uma conexão emocional, ser tocado por um sentido maior de pertencimento.

Deste modo, quando o perfil @Instamission promove uma espécie de "brincadeira digital", congraçando usuários e os patrocinadores em um mesmo espaço, um pacto tácito de confiança nos valores apregoados pela marca é estabelecido promovendo a empatia, a possibilidade de "colocar-se no lugar do outro", neste caso, produzir material institucional a partir dos fragmentos capturados pelo "olhar do outro" participante da missão fotográfica. Assim, o Itaú de certo modo "empodera" o consumidor nesta co-produção compartilhada, enquanto parte inventiva na dinâmica do consumo de imagens em rede ao passo que retroalimenta a sua atenção, capitalizando-a.

Esta estratégia põe em movimento um jogo lúdico que proporciona aos participantes uma experiência estetizante de produção de conteúdo, o que Lipovetsky e Serroy (2015) denominam criticamente como sendo "trabalhar para consumir", ou seja, as instâncias de produção até então fortemente departamentalizadas, mostram-se interpenetradas às práticas e hábitos dos consumidores digitais dispersos em rede que, ao criarem imagens que serão publicadas e legitimadas pela marca obtém, a priori, uma experiência de impacto emocional. Assim, ao acionar motivações hedonistas o "eu quem fiz" dos prosumers, a atual configuração do capitalismo mobiliza os afetos e sensibilidades de seus agentes transformando o consumidorprodutor em uma espécie de artista cujas dimensões estético-imaginárias-emocionais são obtidas pela estetização da experiência de produção e consumo.

Embora na época da definição do conceito de hipermodernidade, as redes sociais engatinhassem e não existisse sequer o Instagram, o caráter paradoxal de se fotografar, utilizando-se da tecnologia mais avançada (representada pelo smartphone), buscando com isso um efeito estetizante através de filtros que evocam o nostálgico, já era apresentado por Lipovetsky (2004):

3 Idealizada por Chris Anderson, propõe que a ambiência da internet, suas dinâmicas e ferramentas de medição possibilitam antever sucessos comerciais para além da lógica dos hits (campeões de vendas típicos da massificação) impulsionando a segmentação de mercados e a formação de nichos de consumo até então negligenciados. 
[...] esse retorno revigorado do passado constitui uma das facetas do cosmo do hiperconsumo experiencial: trata-se não mais de apenas ter acesso ao conforto material, mas sim de vender e comprar reminiscências, emoções, que evoquem o passado, lembranças de tempos considerados mais esplendorosos. Ao valor de uso e ao valor de troca se junta agora o valor emotivo-mnêmico ligado aos sentimentos nostálgicos. Um fenômeno indissociavelmente pós- e hipermoderno. Pós porque se volta para o antigo. Hiper porque doravante há consumo comercial da relação com o tempo, pois a expansão da lógica mercantil invade o território da memória. (LIPOVETSKY, 2004, p. 89).

$\mathrm{O}$ autor reconhece que um dos princípios básicos do Advertainment versa sobre atrair atenção utilizar a simpatia como modo de desbanalizar a marca, isto porque há cada vez mais uma "busca obsessiva e lúdica" de comunicação, de compartilhamento, de vínculo por parte destes usuários hiperconsumidores, visto que os critérios tradicionais de pertencimento social do indivíduo se deslocaram na contemporaneidade para os grupos de filiação espontânea como o de fãs.

Não obstante o conceito de fã aponte originalmente para grupos marginalizados, hoje refere-se a indivíduos inventivos e conscientes da sua relação com o universo criado em torno de um bem de consumo e que, a partir deste, reinventa seus signos, cultura e até mesmo sistema de valores e crenças, os denominados Lovemarks, conforme Kevin Robert (2005).

Assim, aodespertar filiações espontâneas, redimensiona-se quantitativaequalitativamente a noção de audiência, fazendo menção não mais à mera visualização do conteúdo, mas à efetiva atenção dedicada e à conversão desta em engajamento imersivo online.

O apelo do Instamissions é oferecer uma publicidade de verniz menos autoritária em que o consumo decorre não somente da visualização das imagens e seu compartilhamento nas redes, mas em proporcionar ao público uma experiência emocional e sensorial nas esferas da produção e recepção, para que este transforme em experiência estética os relatos da vida cotidiana capturada pelas lentes de seu smartphone, nas palavras de Lipovetsky (2004):

São novas estratégias empregadas pelas empresas, que contribuem para constituir um novo modelo econômico em ruptura com o capitalismo da era industrial. Diferentemente da regulação fordiana anterior, o complexo econômico-estético é menos centrado na produção em massa de produtos padronizados do que nas estratégias inovadoras, quais sejam, a diferenciação dos produtos e serviços, a proliferação da variedade, a aceleração do ritmo de lançamento de novos produtos, a exploração das expectativas emocionais dos consumidores: um capitalismo centrado na produção foi substituído por um capitalismo de sedução focalizado nos prazeres dos consumidores por meio das imagens e dos sonhos, das formas e dos relatos. (LIPOVETSKY, 2004, p. 333).

\section{Estratégias de visualidade do itaú com a \#instamission38}

Neste momento, nos deteremos no relacionamento da empresa Itaú com seus públicos relativos ao ambiente virtual do Instagram através do projeto colaborativo de fotografia Instamission. Segundo Fernando Chacon (2014), diretor de marketing da instituição financeira, a aposta no digital começou em meados dos anos 2000 a partir da emblemática campanha I-Digital (a qual o “i” do Itaú se convertia em @), sintetizando o encontro da virtualização dos 
processos com a personalização no trato com os clientes, expresso então no slogan "banco feito para você".

Em 2010, após a maturação da fusão com o Unibanco, a instituição assume uma nova identidade corporativa com um propósito de marca que se estende até o presente momento: ser um agente de transformação. Este posicionamento de compromisso com a transformação do mundo vem ao encontro da ambição autodeclarada - expressa no relatório anual de 2010 - de ser "o banco líder em performance sustentável e satisfação dos clientes" materializado também através do incentivo a práticas culturais, que vão desde a disponibilização de bicicletas com o conceito de bike sharing (bicicleta compartilhada) em todo país, além de campanhas que estimulam a leitura para crianças, entre outras.

Apesar do forte viés de função mercadológica aí inscrito, estas experiências diversificadas associadas à marca juntamente com outras - a exemplo do Rumos Itaú Cultural, o Espaço Itaú de Cinema, o Itaú viver Mais - reconfiguram as possibilidades de participação e envolvimento com a marca e seus valores, mostrando-se vantajosas em termos de percepção positiva perante seus variados públicos de relacionamento. Afinal, a imagem corporativa não se refere apenas ao desempenho financeiro satisfatório da companhia, mas principalmente as representações mentais construídas (coletiva ou individualmente) mediante experiências reais com a marca, envolvendo assim tanto a cognição como a afetividade.

O valor de uma marca, neste sentido, expressa também o investimento na gestão dos relacionamentos com os múltiplos públicos de interesse. De acordo com o Site Portal da Propaganda, o Itaú é detentor do título de marca mais valiosa do Brasil, há mais de 12 anos seguidos.

Deste modo, quandoo Itaú patrocina missão 38, intitulada:\#Instamission 38: "Fotografe o que transforma o mundo", alcançando a marca de 1.618 fotos publicadas espontaneamente e premiando os ganhadores através da inserção do uso das fotografias vencedoras no filme colaborativo exibido no Prêmio Trip Transformadores em outubro de 2011 - além de presentear com câmeras analógicas Instax Mini 35 e 5 Lomo as cinco melhores imagens - sobrepõe-se com maior clareza a singularidade destas iniciativas como modo de oferecer experiências de entretenimento alinhadas às estratégias de visibilidade da marca no regime de visualidade contemporâneo. 
Figura 1: Convocação para \#instamission38: “Fotografe o que transforma o mundo”.

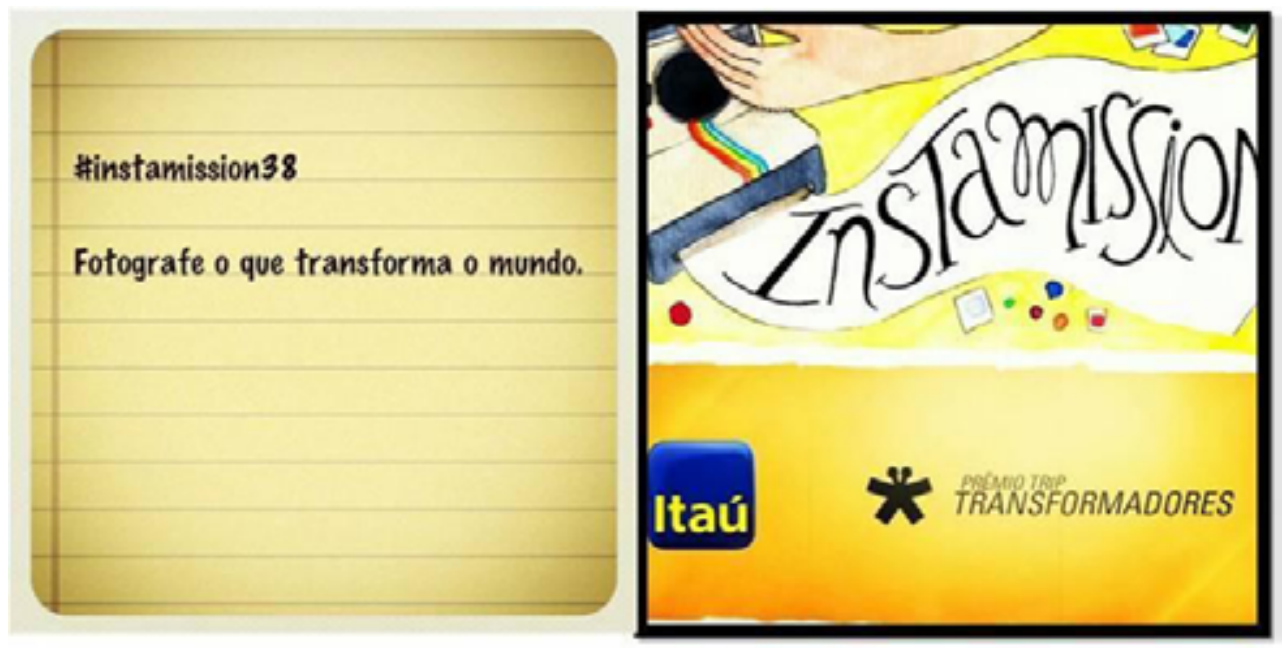

Fonte: Instagram Instamission (2011)

Importante salientar que durante a realização do \#instamission38: "Fotografe o que transforma o mundo", a mídia social Instagram ainda era acessível apenas a usuários do Iphone, embora quem não dispusesse do smartphone da Apple pudesse participar das missões, postando suas fotos no perfil do Instamission no Facebook ou no Twitter, marcando as referidas imagens sempre com a hashtag \#instamissions38. De qualquer modo, esse dado denota que o público participante deriva de uma classe mais abastada, algo que se conforma com o perfil dos clientes do banco. Também não houve nem regulamento oficial nem hierarquia entre as fotos vencedoras, o que vai ao encontro do ar despojado proposto pela ação promocional.

Partiremos da análise das dez fotografias vencedoras da missão \#instamission38: "Fotografe o que transforma o mundo" para, inspirados na tentativa de ensaio metodológico proposto por Martine Joly (2007) em “Introdução a Análise da Imagem”, perceber as estratégias de visualidade implicitamente empregadas.

A onipresença do termo "imagem", seja ela fabricada ou natural, real ou virtual, fixa ou móvel, profana ou sagrada, digital ou analógica, pode levar a desdobramentos de toda ordem, porém, há um consenso de que, independentemente da sua constituição, a imagem quer falar sobre algo, comunica e se todo signo é definido como a capacidade de representar este ente ausente, decerto a imagem como representação de um objeto também será um signo.

Esta constatação marcou a Semiologia e a Semiótica, abrindo uma chancela para diversas vertentes de análise entre as quais destacamos brevemente as abordagens de Roland Barthes e Charles S. Peirce visto que o entrelaçamento destas visões contribuiu para a sedimentação do pensamento elaborado por Martine Joly (2007), autora destaque em nossa proposta de metodologia.

Barthes (1990) no seu clássico texto “A retórica da imagem” representou o primeiro esforço em prol da análise dos objetos da cultura de massa, notadamente da mensagem publicitária, estabelecendo uma metodologia de análise de viés estruturalista em que, a partir 
dos significados atrelados à mensagem publicitária encontram-se seus significantes. Deste modo, identificou na publicidade das massas Panzani três tipos de mensagem: a linguística, a conotada ou simbólica e a denotada ou icônica, acentuando a relação intrínseca entre esses três níveis da mensagem.

Peirce (1977), por sua vez, estabelece um modelo específico de teoria acerca dos signos, dividindo-os de acordo com a relação existente entre o signo e o objeto representado, dando origem à tríade composta pelo: ícone, índice e símbolo, na qual estes exemplificam, respectivamente uma relação de semelhança; causa ou convenção, refletindo também nas relações de primeiridade, secundidade ou terceiridade.

Joly (2007), em “A introdução à análise da imagem”, com o intuito de investigar acerca das mensagens implícitas em uma comunicação publicitária, parte da teoria semiótica americana esboçada por Peirce (1977) para, juntamente com a metodologia de análise criada por Barthes, destacar as escolhas expressivas como a tipografia, as cores, e todo um universo de signos sejam eles plásticos, icônicos ou linguísticos que orbitam a significação global de uma mensagem publicitária. Esta lente interpretativa representou uma maior complexidade para o estudo da imagem, pois além de reconhecer a sua heterogeneidade em múltiplos contextos socioculturais, pôs em relevo elementos antes negligenciados a exemplo da importância dos signos plásticos.

Seu interesse em investigar os aspectos implícitos da imagem publicitária revela o quanto esta é percebida, não mais sobre o aspecto da franqueza ou de uma "transparência" conforme atribuído por Barthes (1990), ao contrário, pois apesar de entender o viés enfático da comunicação publicitária, Joly reconhece, no entanto, a impossibilidade de captar com fidelidade as reais intenções do autor. Assim, advoga em prol de uma interpretação não totalizante o que em suas palavras seria verdadeiramente uma "pretensão incabível" restando aos "consumidores e leitores de imagens" uma interpretação possível e plausível desde que apoiada na recepção e seus backgrounds.

Deste modo, seu objetivo de reconhecer o implícito, a leva executar a metodologia operacionalizada por Roland Barthes “às avessas”, ou seja, começando por descrever a superfície visual para em seguida segmentá-la conforme categorias, trazendo a mensagem plástica como um novo nível de mensagem juntamente com a icônica e linguística. Para tal, analisou o anúncio da marca de vestuário Marlboro Classics publicado na Revista Nouvel Observateur de outubro de 1991.

Enquanto a mensagem icônica envolve conceitos estabelecidos por determinada cultura, exigindo do receptor o conhecimento prévio destas convenções, as mensagens plásticas constituem as formas, cores, diagramação, enquadramentos e demais escolhas expressivas enquanto signos plenos. No que tange às mensagens linguísticas, estas retomam a tradição de ancoramento dos elementos linguísticos enquanto complementares da linguagem visual.

Neste artigo, nos apropriamos do ensaio metodológico proposto por Joly, embora soubéssemos que este não daria conta de um processo total de efeito de sentido, de modo que, 
ao longo da feitura das análises percebemos que a mensagem icônica, ainda que amparada na mensagem linguística, não seria suficiente para abarcar o cultural e seus desdobramentos em termos de efeito de sentido, por isto recorremos a uma nova categoria: a simbólico-cultural.

Para Joly, a imagem em seus usos contemporâneos tornou-se efetivamente um sinônimo de publicidade o que nos leva a indagar sobre como a marca Itaú usa a imagem para engajar e o que promoveria a adesão à prática fotográfica através das missões no Instagram. A coleta das imagens vencedoras foi realizada dia 19 de setembro de 2014, usando a ferramenta Web.Stagram.com, sendo realizada das 14:05h compreendendo um período entre 14:05 às 15:43 do mesmo dia.

O sujeito que experimenta a imagem fotográfica e com ela mantém uma relação de síntese estética revela-se ao mesmo tempo receptor das diversas sensações como também doador de sentido e significação ao que observou. Essa visão que assiste ao mesmo tempo em que também é capaz de produzir sentido é sintomática das transformações oferecidas pelos dispositivos de visualização e seus sistemas. Neste âmbito, Crary (2012) responsabilizou a câmera fotográfica pelo reposicionamento do ato de olhar ancorando-o na corporeidade de seu observador, possibilitando com isso que a subjetividade deste emerja através dos novos níveis de protagonismo oriundos de uma visão corporificada.

Vale aqui destacar que a noção de estratégias de visualidade, um recurso estético de engajamento empregado pela comunicação marcária, pode ser melhor definida por Rocha (2006):

[...] associa-se, portanto, a mecanismos sócio-culturais partilhados que conferem, a determinadas imagens visuais, a qualidade de partícipes de sistemas de crença e de leitura visual reconhecíveis e reconhecidos. O que é visível remete menos ao que se tornou imagem visual e mais àquela visualidade que, via jogo societal e estratégias comunicacionais, é reconhecida como dotada de valor de troca simbólico e de relevância comunicativa. Visibilidade, finalmente, apenas se realiza e se consuma no momento do consumo, da recepção, da codificação, da interpretação e da tradução. É, ainda, um recorte significante particular feito em um todo visual múltiplo e abrangente" (ROCHA, 2006, p.10).

Logo, deixamos claro que a mensagem simbólica cultural apresentada no trabalho, é apenas um dos olhares possíveis e não tem por finalidade esgotar o tema, justamente pela compreensão de que os sujeitos são capazes de construir e reconstruir novas significações a partir de seus backgrounds culturais, repertórios e vivências. Repertório que necessariamente é atravessado pela cultura e dele emerge.

\section{Das mensagens plásticas}

Percebemos a predominância de determinadas características plásticas dentre as fotografias vencedoras: 
Figura 2: As 10 fotografias vencedoras da \#instamission38. "Fotografe o que transforma o mundo"
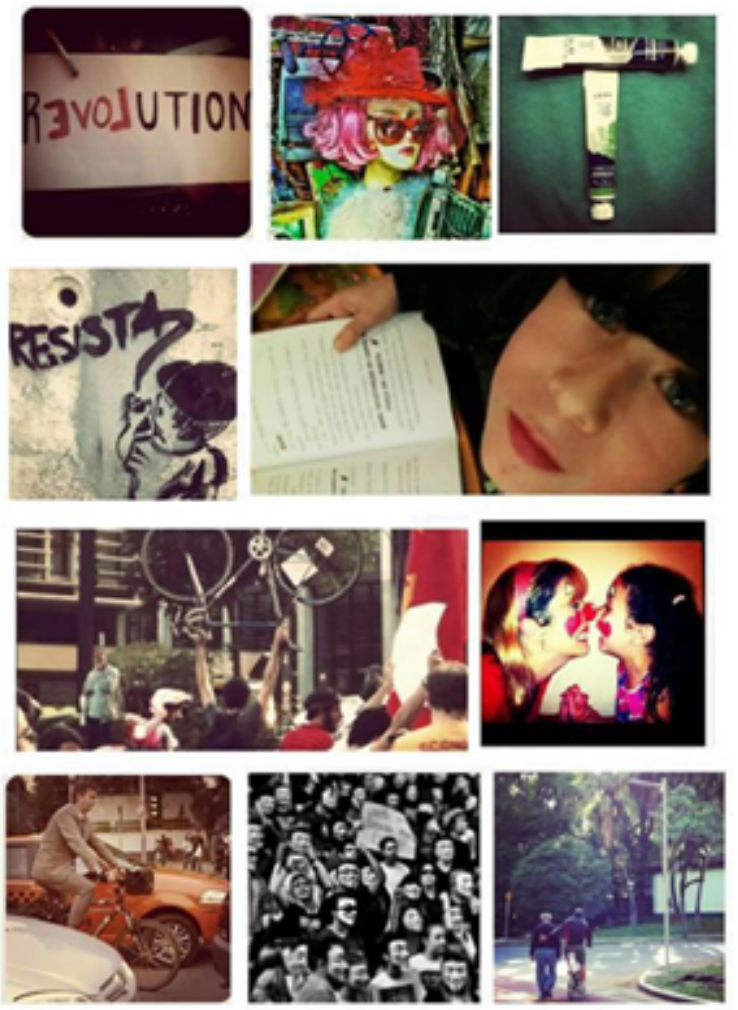

Fonte: Instagram Instamission (2011)

A predileção por molduras convencionais que completam todo o objeto, restando poucas iniciativas não conservadoras (apenas duas fotografias entre as 10 selecionadas).

» Uma ligeira preferência por enquadramentos fechados que sugerem a proximidade com o objeto retratado (seis fotografias).

» Os ângulos que reforçam o sentido de normalidade foram os mais utilizados (seis fotografias), a novidade foi o uso do ângulo de trás (duas fotografias) e do plongée (duas fotografias).

» Predileção pela baixa saturação da cor nas imagens (seis fotografias).

As estratégias de visualidade empregadas reforçam as escolhas estéticas amplamente em voga, como o uso excessivo da baixa saturação da cor, ângulos que reforçam o olhar normatizado e que circunscrevem todos os limites do objeto, embora estes enquadramentos sejam um modelo canônico que obedece às leis da perspectiva - ao contrário de uma estética contemporânea em que há um grau maior de indefinição na imagem - ainda sim é possível alegar a existência de espaços offs. Logo, o uso convencional deste enquadramento não impede uma maior abstração ou uso da criatividade para reconstruí-los.

Percebe-se ainda uma relação direta entre a mensagem solicitada pela campanha e as imagens realizadas pelos participantes, causando muitas vezes o efeito de reiteração das fotos, um didatismo por vezes oriundo da necessidade de clareza com a temática a fim de evitar 
grandes distorções ao que foi proposto, embora mesmo aqui tenha ocorrido a subversão do conceito de transformação solicitado através da foto onde vemos uma passeata de sujeitos mascarados ao estilo Guy Fawkes.

Apesar da missão propor uma aproximação com os usuários através do despojamento do ato de fotografar mediante câmeras acopladas a celulares, nota-se que as fotografias vencedoras não são aquelas oriundas de câmeras de baixa qualidade ou que possuem imagens pixeladas, pelo contrário trata-se de imagens com certo rigor estético seja na escolha dos objetos, enquadramento ou jogo de luz e cor. A esse respeito, notamos que as fotografias vencedoras são de profissionais, fotógrafos ou design gráficos, indivíduos com estreita relação com o mundo das artes imagéticas.

No entanto, embora tenha existido um maior cuidado no que tange ao aspecto plástico da imagem, seu conteúdo é variado indo de fotos modestas (dois tubos de tinta dispostos perpendicularmente conforme a terceira foto) a fotos complexas (seria a modelo da segunda foto uma mulher ou um manequim?).

Portanto, há uma aproximação com os usuários através das missões, pela praticidade e acessibilidade à brincadeira, porém esta adesão nem sempre se traduz em consagração nas redes, devido a considerável exigência de qualidade do material, o que eleva o nível entre os selecionados. De todo modo, as imagens disponibilizadas em rede com a hashtag do \#instamission38: “Fotografe o que transforma o mundo" fazem parte do escopo dos novos modos de publicidade atrelado à experiência de entretenimento.

\section{Das mensagens icônicas}

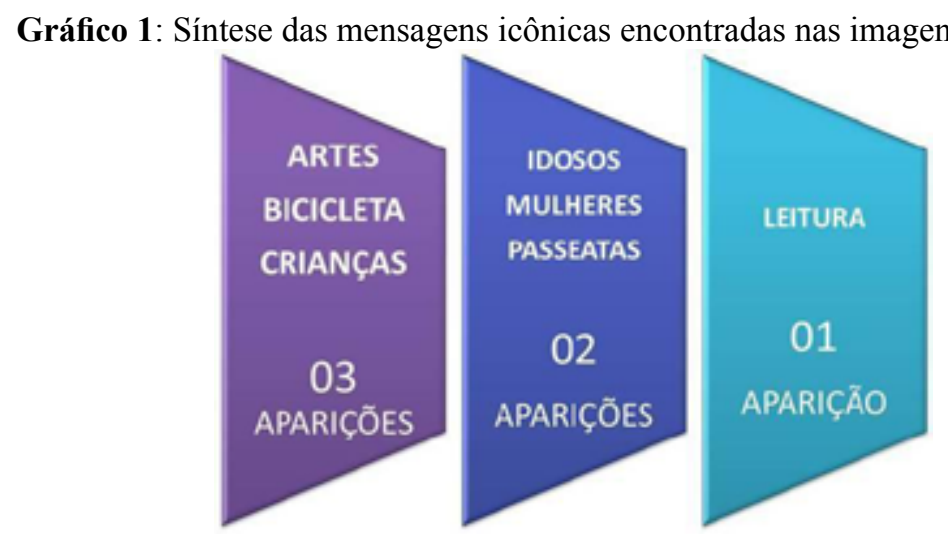

Fonte: Araújo (2016, p.86)

Interessante notar que os elementos icônicos representados pelo Grupo 1: Arte, Bicicletas e Crianças cada um com três aparições se relacionam intrinsicamente com as temáticas abordadas pelo Itaú em suas iniciativas, a exemplo do Itaú Cultural que promove inúmeras linguagens artísticas, do sistema de Bike Compartilhada e do Projeto Leia para uma Criança, todos em atividade. 
Com duas aparições cada uma estão os demais temas do Grupo 2: Idosos, Mulheres e Passeatas, novamente a inserção de idosos nas fotografias remetem ao programa "Itaú Viver Mais" no qual são realizadas atividades físicas e socioculturais para pessoas acima dos 55 anos de todo o país (sejam elas correntistas do banco ou não). Quanto ao tema Mulheres, este se relaciona ao programa educacional Itaú Mulher Empreendedora, visto que as mulheres são a maioria das trabalhadoras autônomas do país.

Até o momento, todas as imagens icônicas (até mesmo as imagens de passeatas aparentemente pacíficas) estavam diretamente alinhadas com o discurso praticado pela instituição financeira em seus diversos canais de comunicação, a saber, baseados sempre no tripé inovação, sustentabilidade e cidadania.

Porém, um olhar mais atento nos leva a crer que uma fotografia destoa do conjunto, pois escolher a imagem de uma passeata com sujeitos vestindo a máscara de Guy Fawkes cabe interpretações que os associam a anarquistas, hackers e aos movimentos antiglobalização como o Occuppy Wall Street em 2008 e aos Black Blocks das Jornadas de Junho de 2013, exaltando seus métodos e práticas. Assim, apesar de existir a filtragem e seleção prévia de imagens, percebemos a existência de um pequeno potencial de "subversão" aos interesses da marca. Ademais, o conjunto de imagens nos informa acerca do universo discursivo da marca e seus valores, em um reforço institucional.

\section{Das mensagens simbólico-culturais}

A palavra transformação possui um apelo atemporal, pois obviamente a todo o momento as coisas do mundo se transformam, porém, ao final do século XX, a sua popularidade disparou, de modo que além do cursar da ordem do natural, conclama-se a transformação das pessoas e a renovação de suas crenças e hábitos.

A missão fotográfica privilegiou uma coleção de fotografias cujos textos imagéticos e linguísticos tangenciam o termo, a exemplo dos subtemas revolução, resistência e amor imediatamente percebidos, contudo detentores de novos contornos de sentido quando analisados em conjunto.

Comecemos pelo termo revolução, que se distancia dos ícones ligados a uma geração analógica em que livros, militância social, bandeiras e cartazes restringiam o universo representacional para dialogar com um cenário mais amplo que inclui as novas linguagens artísticas a exemplo do grafitti. Com efeito, o discurso predominante sobre a revolução aqui proposta é a recusa do embate direto (é o revolution formando o love, a parede rajada de tiro e arte) a resistência através da arte engendrando um outro modo de produzir e consumir que não recusa a sociedade do consumo, aliás é regida perante a batuta do capitalismo tecno-informacional, revestindo-a sob o verniz de uma atitude estetizante, solidária, humanista, amorosa diante do futuro, por que não dizer ecologicamente sustentável - a exemplo da bicicleta - veículo das reivindicações e anseios da época. 
Neste sentido, as fotografias, ao se disseminarem nos meios virtuais através do Instagram, constatam um modo de protesto que reflete o atual cenário das lutas contemporâneas, do asfalto diretamente para as timelines digitais. De modo que ao acolher este novo modelo de ativismo fortemente alicerçado em fotos e hashtags, a instituição financeira legítima e forja uma empatia e cumplicidade com estes modos de estar e perceber o mundo contemporâneo perante o olhar de seu público.

A ideia de dar "autonomia" ao usuário para fotografar "o que transforma o mundo" designa modificações culturais recentes e gera efeitos de sentido forjados na concepção de mudanças estruturais e ideológicas, o que pode ser observado desde a seleção das imagens vencedoras, coordenadas com perfeição com os ideais estéticos do banco Itaú.

\section{Conclusão}

Neste cenário de hipervalorização da imagem, o trabalho buscou compreender como a marca Itaú constrói o engajamento através dos efeitos estéticos proporcionados pela singularidade da fotografia.

Percebeu-se que a instituição financeira Itaú, ao solicitar o clique de momentos, ideias, conceitos que despertam imaginários acabam por forjar uma estética do engajamento na qual se fotografa para compartilhar um olhar transformador estimulado pela mobilização em prol de pequenas atitudes que possam ser traduzidas com o bem-estar da coletividade.

Se o Branded Content pode estar relacionado a outras práticas promocionais no campo da publicidade, pudemos notar que a ação do Instamissions se trata de uma estratégia apoiada na linguagem fotográfica para promover dispositivos de engajamento que se valem do imaginário simbólico da cultura contemporânea.

A estética do engajamento é então programada pelo Itaú e funciona do ponto de vista instrumental, posto que o indivíduo energizado pelas redes passa a ser um fiador, endossando a credibilidade da marca. Neste sentido o papel da internet se destaca, visto que o contexto técnico informacional contribuirá, não só para a interação com o público, mas a própria construção deste que acede às estratégias concebidas previamente pela instituição financeira.

Portanto, alinhar sua campanha institucional ao conceito de "compromisso com a transformação do mundo" não é buscar nas fotografias uma historicidade compatível com as narrativas da tradição e da memória, mas munir o olhar deste observador (ainda que instrumentalmente), para escrever novas histórias, novas percepções dotando-o de artisticidade, humanidade, cidadania valores caros neste início de milênio.

Vale ressaltar que, através das análises empregadas, percebeu-se a existência de um engajamento que estimula a participação lúdica por meio da fotografia em redes móveis, mas que privilegia e celebra as escolhas estéticas consagradas, oriunda de um grupo seleto de produtores de conteúdo imagético. Certamente ao fotografar com a hashtag do \#instamission38: “Fotografe o que transforma o mundo", a instituição financeira Itaú investe no conteúdo gerado 
por usuário como uma estratégia de baixo investimento e grande apelo para uma comunidade construída em torno da experiência com a marca adquirindo um retorno de capital simbólico, um capital estetizante de lembrança junto ao seu público. O Instamission em contrapartida firma-se como mais um dispositivo de ressignificação da cultura e espaço para o estabelecimento de uma comunicação marcária.

Deste modo, apesar da ação do Instamission não ser essencialmente nova em sua essência, pois debruça-se no rol das ações promocionais, espectro habitual da publicidade, representa atualização às ações de outros tempos, pois ao mudar o ambiente e as condições faz emergir novos modos e níveis de interação que sinaliza o comportamento deste consumidor em proximidade com o comportamento de fã.

Por fim, a instituição Itaú, juntamente com o projeto colaborativo de fotografia Instamission, lança mão da estética do engajamento como modo de operacionalizar as estratégias de visibilidade da referida marca, ganhando confiança e adesão junto aos seus consumidores, clientes e usuários no regime de visualidade contemporâneo.

\section{Referências}

ARAÚJO, Larissa Neves. Estética do engajamento do Itaú na \#Instamission38: análise das estratégias de visualidade e dos comentários das fotografias vencedoras / Larissa Neves Araújo. - 2016. 104 f.: il.

BARTHES, Roland. A retórica da imagem. In: O óbvio e o obtuso. Rio de Janeiro: Nova Fronteira, 1990.

CHACON, Fernando. Banco Itaú: O desafio de se tornar inconfundível. Porto Alegre. Palestra ministrada no Congresso de Marketing da ADVB em 31 outubro de 2014.

COVALESKI, Rogério. Publicidade Híbrida. Curitiba: Maxi Editora, 2010.

CRARY, Jonathan. Técnicas do observador: visão e modernidade no século XIX. Rio de Janeiro: Contraponto, 2012.

GUMBRECHT , H. U. Pequenas crises: experiência estética nos mundos cotidianos. In; GUIMARÃES, C. G. (Org.); LEAL, Bruno Souza (Org.); MENDONÇA, Carlos Camargos (Org.). Comunicação e Experiência Estética. $1^{\mathrm{a}}$ ed. Belo Horizonte: Editora da UFMG, 2006.

JENKINS, Henry. Cultura da convergência: a colisão entre os velhos e novos meios de Comunicação, São Paulo: Aleph, 2006.

JOLY, Martine. Introdução à Análise da Imagem. (Trad. José Eduardo Rodil). Lisboa: Edições 70, 2007.

LEMOS, André. Cidade e mobilidade. Telefones celulares, funções pós-massivas e territórios informacionais. Revista Matrizes, n. 1, 2007 
LIPOVETSKY, Gilles. Os Tempos Hipermodernos. São Paulo: Barcarolla, 2004.

LIPOVETSKY, Gilles; SERROY, Jean. A estetização do mundo: Viver na era do capitalismo artista. Tradução de Eduardo Brandão. $1^{\text {a }}$ ed. São Paulo: Companhia das Letras, 2015.

Matéria intitulada "Itaú é eleito novamente a marca mais valiosa do Brasil" disponível desde 04.12.2015 no Portal da Propaganda. Disponível em: <http://portaldapropaganda.com.br/noticias/3105/itau-e-eleito-novamente-a-marca-mais-valiosa-do-brasil/>.Acesso em: 12 dez.2017.

PEIRCE, C. S. Semiótica. São Paulo: Editora Perspectiva, 1977.

ROBERTS, Kevin, Lovemarks: o futuro além das marcas. São Paulo: Books, 2005

ROCHA, Rose de Melo. Cultura da visualidade e estratégias de (in)visibilidade. In: Revista da Associação Nacional dos Programas de Pós-Graduação em Comunicação. Disponível em: $<$ http://www.compos.org.br/seer/index.php/e compos/article/viewFile/115/114>.Acesso em: 12 mar.2016

SANTOS, André Bonfim dos. A descompressão do audiovisual publicitário: analisando o processo comunicacional da prática do Branded Content. 2014, 135 f. Dissertação - Universidade Federal da Bahia, Faculdade de Comunicação.

SILVA JR, J. A. Da fotografia expandida à fotografia desprendida: como o instagram explica a crise da Kodak e vice-versa. Revista Líbero, São Paulo, v. 17, n. 33, p. 117-126, jan./ jun. 2014. Disponível em: <https://casperlibero.edu.br/wp-content/uploads/2014/12/11-Jos\%C3\%A9-Junior.pdf $>$. Acesso em: 12 mar. 2017 